\title{
Seasonal dynamics and phytoplankton diversity in high mountain lakes (Jöri lakes, Swiss Alps)
}

\author{
Brigitte HINDER, Matthias GABATHULER ${ }^{1)}$, Beatrice STEINER ${ }^{2)}$, Kurt HANSELMANN ${ }^{3)}$ and Hans R. PREISIG* \\ University of Zurich, Institute of Systematic Botany, Zollikerstr. 107, CH-8008 Zurich \\ ${ }^{1)}$ ETH Zurich, Institute for Atmospheric Science, HPP L 3.2, Hönggerberg, CH-8093 Zurich \\ ${ }^{2)}$ University of Bern, Dept. of Chemistry and Biochemistry, Laboratory of Radio- and Environmental Chemistry, Freiestr. 3 , \\ CH-3012 Bern \\ ${ }^{3)}$ University of Zurich, Institute of Plant Biology, Dept. of Microbiology, Zollikerstr. 107, CH-8008 Zurich \\ *e-mail corresponding author: preisig@sysbot.unizh.ch
}

\begin{abstract}
The development of the phytoplankton in two years with very distinct weather situations was compared. In 1996, the ice on Jöri Lake III melted in mid June, summer stratification persisted during two months, and ice began to build up again in mid October. In 1997, the ice melted only at the end of July, which strongly influenced the development of the phytoplankton. Stratification persisted during two months and the lake froze up towards the end of October. The average chlorophyll-a concentrations were lower in 1996 than in 1997, which reflects the rather high temperatures and stable weather conditions in 1997 after the late melting of the ice. These observations lead us to suggest that the duration of the ice-free season is less decisive for biomass production than the weather conditions during this period. However, the date and duration of melting of the lake ice strongly influence the development of algal species that are typically observed in early season.
\end{abstract}

Key words: phytoplankton, community structure, seasonal dynamics, mountain lake, meteorological conditions

\section{INTRODUCTION}

Organisms of high mountain lake ecosystems are challenged by extreme and extremely variable living conditions, since sudden weather changes are common for high altitudes. The length of the ice-free season as well as the time and duration of ice melting can vary significantly. This affects the relative length of water column stratification, which can last for one to three months between melting and formation of the lake ice cover. The particular conditions which characterize high mountain lakes influence the biomass and community structure of the plankton. For subalpine lakes, Goldman et al. (1989) showed that the relative length of water column stratification followed by a sufficiently long mixing period is very important for the primary production. High mountain lakes undergo major physical restructuring during ice melting in spring and cooling in fall. During these periods, the phytoplankton assemblages change dramatically, and the meteorological conditions exert strong regulatory effects on their development and seasonal succession (Harris 1986; Goldman et al. 1996; Litaker et al. 1993).

At the beginning of this century, Kreis (1921) studied the fauna in 13 of the 21 lakes and ponds in the Jöri catchment, and he described the morphology of the lakes for the first time. About 20 years later, Messikommer (1942) investigated the phytoplankton in the region of Davos, including two of the Jöri lakes.
In this paper, detailed physical, hydrological, chemical and biological features of Jöri lakes III and VII are presented. Furthermore, we compare the development of the phytoplankton over two years and correlate them with distinct weather situations. We show, how meteorological factors affect the development of phytoplankton communities in lakes III and VII, one containing high amounts of suspended erosion particles (III), the other one with clear water (VII).

\subsection{Characteristics of the catchment}

The catchment of the Jöri lakes is located in a remote mountain area of the Eastern Swiss Alps, in the canton of Graubünden, at $46^{\circ} / 46^{\prime} \mathrm{N}$ and $9^{\circ} / 58^{\prime} \mathrm{E}$. The entire basin, which comprises 21 lakes and ponds is $3.05 \mathrm{~km}^{2}$ in area and extends from $2489 \mathrm{~m}$ to $3060 \mathrm{~m}$ a.s.l. Accessibility is more difficult in winter, thus requiring special efforts for measurements of variables that can not be obtained by electronic logging. The ba$\sin$ is generally well shielded by high mountain chains against the west and the south side, but it is open to the north, in which direction the water drains from the catchment. There are 16 lakes in the catchment ranging in size from $500 \mathrm{~m}^{2}$ to almost $0.1 \mathrm{~km}^{2}$ and 5 smaller ponds. The total surface area of all lakes is slightly over $0.2 \mathrm{~km}^{2}$ corresponding to approximately $18 \%$ of the entire catchment area. The Jöri basin was initially formed by the Jöri glacier that is presently retreating, but still covers an area of about $0.3 \mathrm{~km}^{2}$. The lakes show great variability in suspended particle concentrations since 
some get their water directly from the glacier while others receive it only from snowmelt and precipitation runoff. All the lakes lie within the same catchment area which mainly consists of a homogeneous crystalline gneiss formation. The major elements in the rock minerals are Si and $\mathrm{Al}$ (Krähenbühl 1984). The alkalinity in the lakes is about $100 \mu \mathrm{eq} \mathrm{I}^{-1}$ and they are less affected by acidification than the lakes located in the central Alps of the Gotthard region. The surroundings consist mostly of large rocks and some flood plains with erosion mud deposits and only scarce vegetation. Some of the lakes are connected in a cascade-type system which allows to follow chemical and biological changes which occur within a $250 \mathrm{~m}$ altitudinal gradient between the highest and the lowest lakes.

\section{METHODS}

\subsection{Meteorology and Hydrology on-line measurements}

The Jöri weather station is situated on the shore of Lake III at an altitude of $2520 \mathrm{~m}$. Meteorological variables are recorded hourly during winter and spring (November to June) and in 10 minutes intervals during summer and autumn (July to October). Variables measured include air temperature, humidity, precipitation, wind speed and direction, global radiation and incoming long wave radiation. In the water, two chains with 11 sensors each measure the temperature profile of Lake III every 15 minutes.

\subsection{Chemistry}

Samples for lake water analyses were collected biweekly from different depths and filled into polyethylene bottles in a way that no air remained in the bottle. The bottles were kept at $4{ }^{\circ} \mathrm{C}$ until further analysis. The deposition samples were collected either in a Bergerhoff-type collector for bulk deposition (Minger 1996) or in a polyethylene bottle (wet only deposition). The deposition samples were kept at $4{ }^{\circ} \mathrm{C}$ until analysis.

The $\mathrm{pH}$ was measured with a Methrom $\mathrm{pH}$ Meter without stirring but with previous addition of $50 \mathrm{mg} \mathrm{su}-$ prapur $\mathrm{NaCl}$ per $50 \mathrm{ml}$ sample in order to obtain a higher ionic strength. For conductivity measurements a cell with a constant of $1 \mathrm{~cm}^{-1}$ was used and the value was directly normalized to $25^{\circ} \mathrm{C}$. The $\mathrm{pH}$ and the conductivity of lake water samples were measured in situ and double checked in the laboratory. All determinations included a control of the measured conductivity with the conductivity calculated from equivalent conductances of all species analyzed (Marchetto et al. 1996). The quality criteria are fulfilled if the difference between calculated and measured conductivity is less than $15 \%$. Alkalinity was determined by Gran titration (Gran 1950, 1952) with a common Methrom pH Meter 632 in presence of suprapur $\mathrm{NaCl}$ to obtain an ionic strength of $0.1 \mathrm{M}$.

Anions (chloride, nitrate and sulfate) were measured with ion chromatography with chemical suppression
(DIONEX 2000i, separation column AS4A). Calcium, magnesium, potassium and sodium concentrations were determined by ICP-AES (VARIAN Liberty 150 AX Turbo) and double checked in some samples with ion chromatography. Ammonia was analyzed in the same cation chromatogram. SRP (soluble reactive phosphorus) was determined at the site immediately after sampling employing the method of Murphy and Riley (1962).

\subsection{Phytoplankton}

$500 \mathrm{ml}$ samples in PET bottles were taken from three different depths ( $1 \mathrm{~m}$ below surface, thermocline depth and one meter above the bottom) and fixed with Lugol solution. Enumeration of the dominant species of algae was performed using an inverted microscope with phase contrast optics. Biovolume conversion factors were calculated using approximations to geometrical shapes (Straškrabová et al. 1999, this issue). The specific carbon content was calculated from $\mathrm{C}=0.1204 \mathrm{~V}^{1.051}$ using the regression after Rocha \& Duncan (1985).

\subsection{Chlorophyll-a}

Samples were taken with a 3-1 plexiglass water sampler from the different depths. $400 \mathrm{ml}$ to $1000 \mathrm{ml}$ water were filtered through glass fiber filter (GF 6, Schleicher and Schuell, Dassel, Germany) within two hours after sampling. Filters were transported frozen to the laboratory for analyses. Chlorophyll- $a$ concentration was measured after extraction in $90 \%$ acetone using fluorimetric determination after Schanz (1982).

\subsection{Water column profiling}

Water column profiling was done weekly during the ice-free season and at least three times during the icecovered period. Winter sampling was required to determine the oxygen consumption below the ice cover.

Temperature, $\mathrm{pH}$, oxygen and conductivity were measured with a Hydropolytester (Züllig, Rheineck, Switzerland). Turbidity was determined by light scatter loss in a photometer (PU 8625 UV/VIS Spectrophotometer, Philips, Zürich, Switzerland) in $5 \mathrm{~cm}$ glass cuvettes at a wavelength of $660 \mathrm{~nm}$ and transformed to NTU (DEV 1996; 38'404-C2).

\section{RESULTS}

\subsection{Physical characteristics}

\subsubsection{Hydrology}

The lakes in the Jöri catchment area were originally numbered (I to XIII) by Kreis in 1921; we extended the numbering to XXI for those lakes, which have been newly formed during the last 80 years (Fig. 1). The lakes described in this paper are numbers III and VII. 


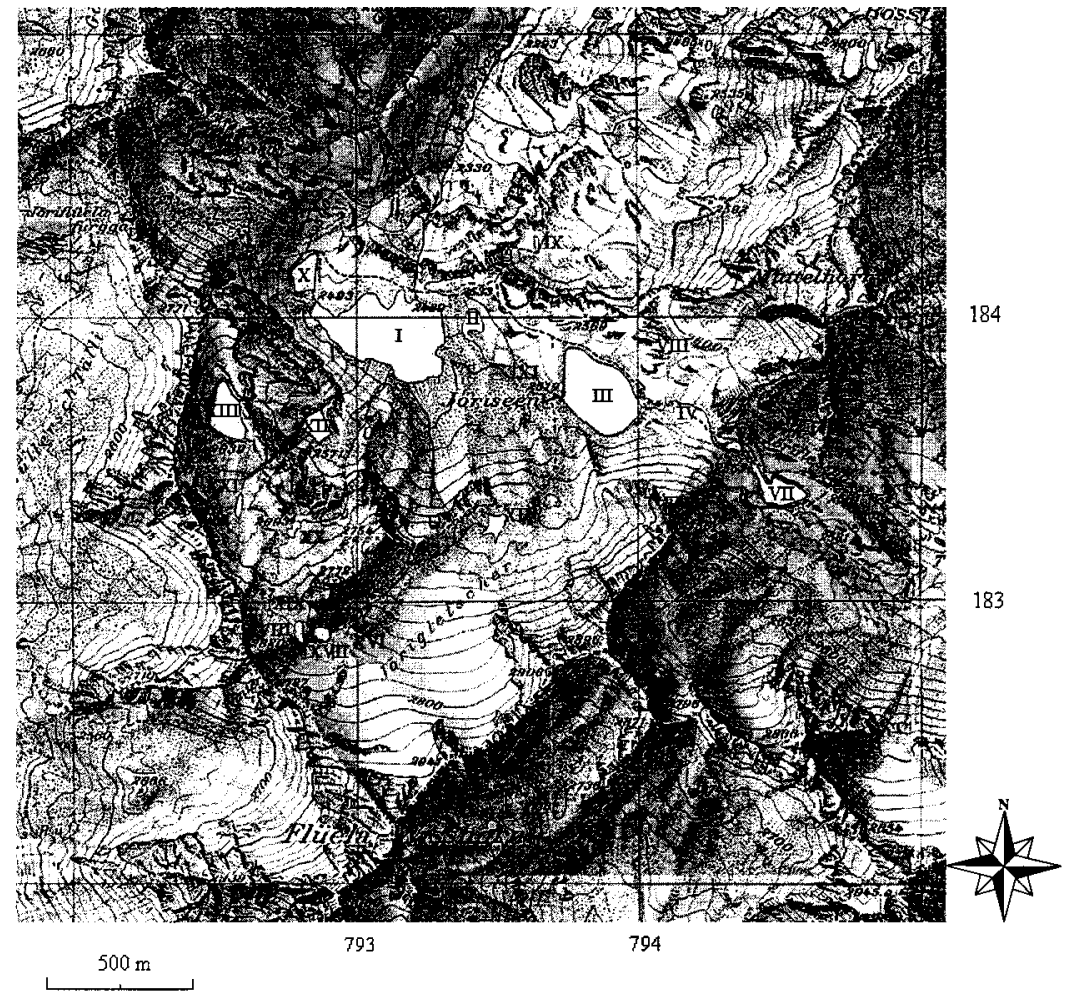

Fig. 1: Map of the study site of the Jöri lakes $\left(9^{\circ} 57^{\prime}\right.$ to $9^{\circ} 59^{\prime} \mathrm{N} / 46^{\circ} 46^{\prime}$ to $46^{\circ}$ $47^{\prime}$ E). Numbering of the lakes after Kreis (1921) (I-XIII) and Summa (XIV- XXI). Reproduction with the kind permission of the Federal Office of Topography, Switzerland, on January 7, 1999.

\section{Hydrology Lake III}

Lake III has the largest volume of all the Jöri lakes (maximum of $600,000 \mathrm{~m}^{3}$ ). The surface area is 57 ' 800 $\mathrm{m}^{2}$ when the lake is completely filled and up to $51000 \mathrm{~m}^{2}$ less in early winter. The catchment is approximately 1.3 $\mathrm{km}^{2}$; it cannot be precisely delineated, however, due to subsurface inflows from the glacier. The annual average water residence time $(\mathrm{R})$ calculated from yearly average precipitation $(\mathrm{P})$, catchment size $(\mathrm{A})$ and lake volume (V), is about 4 months $\left(\mathrm{R}=\mathrm{V} \times \mathrm{P}^{-1} \times \mathrm{A}^{-1}\right)$. Lake III receives some water from the glacier, which makes the lake turbid. Early season Secchi depth can be up to $3 \mathrm{~m}$, but it decreases to less than $1 \mathrm{~m}$ as more turbid water from the glacier is added. Under conditions of high turbidity, $99 \%$ of the global radiation which penetrates into the water is absorbed in the top $3 \mathrm{~m}$. Due to its turbidity and maximum depth of $22 \mathrm{~m}$ the lake can be temperature stratified for up to three months every year.

\section{Hydrology Lake VII}

Lake VII has an area of $11,600 \mathrm{~m}^{2}$ and lies at an altitude of $2557 \mathrm{~m}$ a. s. 1.. Its maximum depth is $8.5 \mathrm{~m}$, its volume approximately $40,000 \mathrm{~m}^{3}$ and its catchment area $0.16 \mathrm{~km}^{2}$. The average water residence time is about 2.5 months. The water in Lake VII is clear to the ground with water inflow from rain and snowmelt only. Secchi depth is always more than $4 \mathrm{~m}$, it can reach more than 8 $\mathrm{m}$ early in the season. It is isothermal for most of the season.

\subsubsection{Meteorology and climatology}

The weather at the Jöri lakes can be characterized by a long cold winter with heavy snowfalls and a short summer with many thunderstorms and a few nice weather spells. Snow may be expected at any day of the year. Maximum air temperatures reach $20{ }^{\circ} \mathrm{C}$ on rare occasions, daily average temperature is usually below zero from November through April. Yearly average temperature is $-2{ }^{\circ} \mathrm{C}$ as measured at the Jöri weather station. This is slightly less than expected, compared with stations at similar altitudes. When the lakes are frozen, cold air tends to accumulate above the lakes, due to the lack of outflow possibilities. The total yearly precipitation is $1400 \mathrm{~mm}$ with approximately $70 \%$ of it falling as snow. Annual average radiation is about $185 \mathrm{~W}$ $\mathrm{m}^{-2}$ (Tab. 1). Winds tend to be strong only on the ridges, but most of the lakes are well shielded by the surrounding mountains. Lake VII on Jörifless Pass usually experiences higher winds than the other lakes which lie deeper in the catchment. Other than exposure to wind, lakes III and VII are similar. Average air temperatures at Lake VII are $0.2{ }^{\circ} \mathrm{C}$ lower than at lake III and due to mountain shading, average global radiation is about 10 $\mathrm{W} \mathrm{m} \mathrm{m}^{-2}$ smaller.

Snow on the horizontal plains usually disappears between mid June and mid August, depending on the season's maximum snow water equivalent and on early summer weather conditions. The break-up date for the lake ice can be at the end of June at the earliest and the 
end of August at the latest for Lake III. Calculations were made on the basis of a snow height adjusted degree day model (M. Gabathuler, unpublished). The break-up date depends on temperatures from May up to the disappearance of the ice and on the snow load on the lakes. Deep lakes as well as lakes at higher altitudes tend to break up later. For the build-up of the ice in autumn, altitude is less important than depth, size and accumulated heat. Owing to their greater heat energy content in the autumn, lakes with large volumes tend to freeze later than small and shallow lakes. The freeze-up date of Lake III falls usually into the second half of in 1996. The same could be observed for the ice cover on the lakes, which did not disappear until the end of July. August was a warm month with precipitation below average. Heavy snowfalls at the end of August caused the stratification in Lake III to weaken temporarily. September was extremely dry with only two precipitation events with a total of $45 \mathrm{~mm}$. The average temperature for this month was $7{ }^{\circ} \mathrm{C}$ higher than in 1996 and 13 cloudless days were recorded. Stratification could be observed until October $2^{\text {nd }}$. Snow covered the area around the lakes from October $12^{\text {th }}$ on; the lake froze around the $26^{\text {th }}$ of that month.

Tab. 1. Air temperature $\left({ }^{\circ} \mathrm{C}\right)$, precipitation $(\mathrm{mm})$ and radiation $\left(\mathrm{W} \mathrm{m}^{-2}\right)$ at Jöri lake III. Long term averages (1981 - 1998) were taken from the SMI (Swiss Meteorological Institute) station at Weissfluhjoch, situated $13 \mathrm{~km}$ from Jöri lakes at an altitude of $2690 \mathrm{~m}$ a. s. 1 .

\begin{tabular}{|c|c|c|c|c|c|c|c|c|c|}
\hline & \multicolumn{3}{|c|}{ 1996, Lake III } & \multicolumn{3}{|c|}{ 1997, Lake III } & \multicolumn{3}{|c|}{ 1981-1998, SMI Weissfluhjoch } \\
\hline & Temp & Prec & Rad & Temp & Prec & $\operatorname{Rad}$ & Temp & Prec & Rad \\
\hline June & 4.2 & 125 & 253 & 2.7 & 232 & 196 & 2.3 & 167 & 239 \\
\hline July & 4.3 & 213 & 234 & 3.6 & 265 & 195 & 5.8 & 182 & 223 \\
\hline August & 4.3 & 197 & 160 & 6.6 & 182 & 186 & 5.8 & 171 & 192 \\
\hline September & -1.1 & 110 & 166 & 6.4 & 45 & 206 & 2.9 & 126 & 163 \\
\hline October & -1.1 & 122 & 124 & -0.3 & 83 & 127 & 0.2 & 69 & 125 \\
\hline Total or average & 2.1 & 767 & 187 & 3.8 & 807 & 182 & 3.4 & 715 & 188 \\
\hline
\end{tabular}

October or the first half of November. Once a lake has reached isothermal conditions, it can freeze when its threshold conditions are fulfilled. These conditions are different for every lake, but always consist of air temperature, wind and average lake water temperature $(\mathrm{Gu}$ \& Stefan, 1990).

Summer started early in 1996; daily average temperatures regularly came close to $10{ }^{\circ} \mathrm{C}$ in early June. Due to the small maximum snow water equivalent for this year, snow melted almost a month earlier than usual. The same can be said for the lake ice covers, which disappeared towards the end of June. Between July and October temperatures were regularly below average, especially in September. The few days with nice and warm weather were recorded during the second half of July, allowing Lake III to get well stratified. The stratification weakened with a cold front which came up in the middle of August and which completely disappeared during a heavy snowfall at the end of August. August was a wet month with precipitation on 24 days reaching $200 \mathrm{~mm}$ in total. Snow constantly covering the area around the lakes started as early as September $13^{\text {th }}$. Although there was no stratification anymore in Lake III after September $2^{\text {nd }}$, a complete ice cover was not observed until October $17^{\text {th }}$.

June and July of 1997 were not only colder and with less global radiation than the same months in 1996, but there was also a much higher maximal snow water equivalent to begin with, which caused the largest differences in the lake processes. It caused the snow around the lakes to melt more than one month later than

\subsection{Chemical characteristics}

Lake III is fed by a subterranean inlet from the Jöri Glacier. In 1996 only surface water had been sampled. Rising concentrations of several ions $\left(\mathrm{K}, \mathrm{Mg}, \mathrm{NO}_{3}\right)$ and therefore increasing conductivity could be observed towards autumn, which was due to the stratification of the lake (Lerman et al. 1995). The main ions found in the two lakes were calcium and sulfate which are also the most important components in the deposition (Tab. 2). Lake VII showed similar, mostly smaller, concentrations of ions than Lake III for both sampling years. For some components, like $\mathrm{K}$ and $\mathrm{Mg}$, it is more pronounced which is probably due to the different water sources of the two investigated lakes. Lake III receives melt water from the glacier, but also rain water and water from upper lakes. In contrast, Lake VII receives mainly rain and spring water. The average concentrations for the measured ions are listed in table 2; they did not change substantially from 1996 to 1997 . Alkalinity values for both years were around $100 \mu \mathrm{eq} \mathrm{l}^{-1}$. TP and total inorganic nitrogen (TN, sum of nitrate and ammonium) concentrations after spring mixing amount to about $10 \mathrm{ppb}$ and $200 \mathrm{ppb}$, respectively. After Wetzel's (1983) trophic state scale, the Jöri lakes are considered as oligotrophic. Increasing TN- and TP-concentrations were measured in the depth profiles towards the sediment (up to $40 \mathrm{ppb}$ TP one meter above the sediment). The same observation was made for turbidity, which could indicate a link between particles and nutrient content. 
Tab. 2. Chemical characteristics of Jöri lakes III and VII in 1996 and 1997. $x$ and s are mean and standard deviation, $n$ is the number of samples analyzed.

\begin{tabular}{|c|c|c|c|c|c|c|c|c|c|c|c|c|c|c|c|c|c|c|c|c|c|c|c|c|c|}
\hline & \multirow[t]{2}{*}{$\mathrm{n}$} & \multicolumn{2}{|c|}{$\mathrm{pH}$} & \multicolumn{2}{|c|}{$\begin{array}{l}\text { Cond. } 25^{\circ} \mathrm{C} \\
\left(\mu \mathrm{S} \mathrm{cm}{ }^{-1}\right)\end{array}$} & \multicolumn{2}{|c|}{$\begin{array}{c}\mathrm{NH}_{4} \\
\left(\mu \mathrm{g} \mathrm{N}^{-1}\right)\end{array}$} & \multicolumn{2}{|c|}{$\begin{array}{c}\mathrm{Ca} \\
\left(\mathrm{mg} \mathrm{l}^{-1}\right)\end{array}$} & \multicolumn{2}{|c|}{$\frac{\mathrm{Mg}}{\left(\mathrm{mg} \mathrm{l}^{-1}\right)}$} & \multicolumn{2}{|c|}{$\begin{array}{c}\mathrm{Na} \\
\left(\mathrm{mg} \mathrm{l}^{-1}\right)\end{array}$} & \multicolumn{2}{|c|}{$\begin{array}{c}\mathrm{K} \\
\left(\mathrm{mg} \mathrm{l}^{-1}\right)\end{array}$} & \multicolumn{2}{|c|}{$\begin{array}{c}\text { Alk. } \\
\left(\mu \text { eq } 1^{-1}\right)\end{array}$} & \multicolumn{2}{|c|}{$\begin{array}{c}\mathrm{SO}_{4} \\
\left(\mathrm{mg} \mathrm{l}^{-1}\right)\end{array}$} & \multicolumn{2}{|c|}{$\begin{array}{c}\mathrm{NO}_{3} \\
\left(\mu \mathrm{g} \mathrm{N}^{-1}\right)\end{array}$} & \multicolumn{2}{|c|}{$\begin{array}{c}\mathrm{Cl} \\
\left(\mathrm{mg} \mathrm{l}^{-1}\right)\end{array}$} & \multicolumn{2}{|c|}{$\begin{array}{c}\mathrm{P} \\
\left(\mu \mathrm{g} \mathrm{P} 1^{-1}\right)\end{array}$} \\
\hline & & $\mathrm{x}$ & $\mathrm{s}$ & $\mathrm{x}$ & $\mathrm{s}$ & $\mathrm{x}$ & $\mathrm{s}$ & $\mathrm{x}$ & $\mathrm{s}$ & $\mathrm{x}$ & $\mathrm{s}$ & $\mathrm{x}$ & $\mathrm{s}$ & $\mathrm{X}$ & $\mathrm{s}$ & $\mathrm{x}$ & $\mathrm{S}$ & $\mathrm{X}$ & $\mathrm{s}$ & $\mathrm{X}$ & $\mathrm{s}$ & $\mathrm{x}$ & $\mathrm{s}$ & $\mathrm{x}$ & $\mathrm{s}$ \\
\hline 1996 & & & & & & & & & & & & & & & & & & & & & & & & & \\
\hline Lake III & 12 & 6.75 & 0.11 & 19.92 & 0.99 & 7.80 & 3.60 & 2.28 & 0.41 & 0.30 & 0.06 & 0.40 & 0.06 & 0.36 & 0.15 & 103 & 52 & 2.99 & 0.24 & 194 & 41 & 0.17 & 0.18 & 36 & 18 \\
\hline $\begin{array}{l}\text { Lake VII } \\
1997\end{array}$ & 8 & 6.70 & 0.10 & 15.74 & 0.79 & n.d. & & 1.71 & 0.14 & 0.20 & 0.02 & 0.33 & 0.03 & 0.24 & 0.07 & 100 & 46 & 1.97 & 0.15 & 179 & 52 & 0.22 & 0.13 & n.d. & \\
\hline Lake III & 38 & 7.15 & 0.54 & 17.90 & 3.90 & 8.80 & 13.60 & 3.15 & 1.32 & 0.40 & 0.15 & 0.52 & 0.18 & 0.38 & 0.14 & 99 & 55 & 2.49 & 0.77 & 254 & 74 & 0.08 & 0.11 & 9 & 8 \\
\hline Lake VII & 5 & n.d. & & n.d. & & 2.60 & 1.30 & 2.27 & 0.65 & 0.25 & 0.07 & 0.33 & 0.09 & 0.24 & 0.05 & n.d. & & 1.48 & 0.39 & 169 & 14 & 0.01 & 0 & 9 & 4 \\
\hline
\end{tabular}

Although up to $80 \%$ of the chemical species which had accumulated in snowpacks are removed with the first $20 \%$ of the melt water, organisms can barely profit from this nutrient peak (Johannessen \& Henriksen 1978). During snow melt, the water in all Jöri lakes is exchanged in less than one month. Since nutrient-rich inflow water has a temperature of around $0{ }^{\circ} \mathrm{C}$, it is lighter than lake water and therefore will not be mixed down to great depths but will exit through a surface outflow within a few days.

\subsection{Biological characteristics}

\subsubsection{Phytoplankton}

Phytoplankton composition in Jöri lakes III and VII

In both lakes the Chlorophyta is the most abundant algal division. Almost all species can be found in both lakes (Tab. 3). Therefore, phytoplankton biodiversity in terms of the number of species is about the same in lakes III and VII. The dominance and the abundance of the species differ considerably, however (Fig. 2).

Tab. 3. Dominant species of algae in Jöri lakes III and VII.

\begin{tabular}{ll}
\hline Chlorophyta & Eutetramorus fottii \\
& Dictyosphaerium subsolitarium \\
& Monoraphidium subclavatum \\
& Chlamydomonas braunii \\
Cryptophyta & Rhodomonas lacustris \\
Chrysophyta & Dinobryon cylindricum var. alpinum \\
& Kephyrion doliolum \\
& Chromulina sp. \\
& Chrysococcus furcatus \\
Dinophyta & Gymodinium lantzschii \\
& Amphidinium elenkinii
\end{tabular}

In Lake III several species develop with almost the same dominance, but still Eutetramorus fottii is the most abundant species. As Eutetramorus fottii is a rather large algae, it consequently represents an important fraction of the total algal carbon content of Lake III (Fig. 2). In Lake VII only few species dominate the community: Dictyosphaerium subsolitarium in early season, as well as Gymnodinium lantzschii (1996) and Monoraphidium subclavatum (1997) towards the end of the season. In Lake VII cell numbers are higher than in
Lake III. This is due to the dominant but small species Dictyosphaerium subsolitarium. Taking biovolume and specific carbon content into consideration, biomasses in Lake III are distinctly higher.

Seasonal dynamics

Both lakes show strongly developed seasonal dynamics. Comparing the two years 1996 and 1997 it seems that the date of the ice melting is very important for the development of some species. In 1996 when the ice melted early (late June) Rhodomonas lacustris developed rapidly and dominated in the first weeks of the ice-free period in Lake III (Fig. 3). After one month, the Chlorophyta (Dictyosphaerium subsolitarium and Eutetramorus fottii) appeared in higher cell numbers and started to dominate the community (Fig. 3). On a Ccontent basis, Eutetramorus fottii was the most dominant taxon. Towards the end of the ice-free season, Kephyrion doliolum, and Monoraphidium subclavatum also developed well. In 1997, when the ice melted very late (end of July), there was a great number of cysts, mainly of Chrysophyta, which sometimes persisted during almost the entire season. After the late melting of the lake ice, it took longer for biomass production to take off than the year before. An exception was Dinobryon cylindricum var. alpinum, which developed even better than the year before (Fig. 3). On a C-content basis, it was by far the most dominant taxon in July and August. In contrast to 1996, Rhodomonas lacustris was very scarce. Chlorophyta development was one month late compared to 1996, but towards the end of the season, Eutetramorus fottii, Dictyosphaerium subsolitarium and Monoraphidium subclavatum propagated even better. In summary, the proportional composition of the algal divisions differed significantly in the two years: Cryptophyta, which were typical for the early season in 1996, did not develop well during the entire season of 1997. In the second part of the ice-free season, Chlorophyta were even more dominant in 1997 than in 1996 (Fig. 4). For Lake VII similar observations have been done (data not shown).

\subsubsection{Chlorophyll- $a$}

Chlorophyll- $a$ concentrations in Lake III range from 0.4 to $5.0 \mu \mathrm{g} \mathrm{l}^{-1}$. In 1996 average concentrations were 

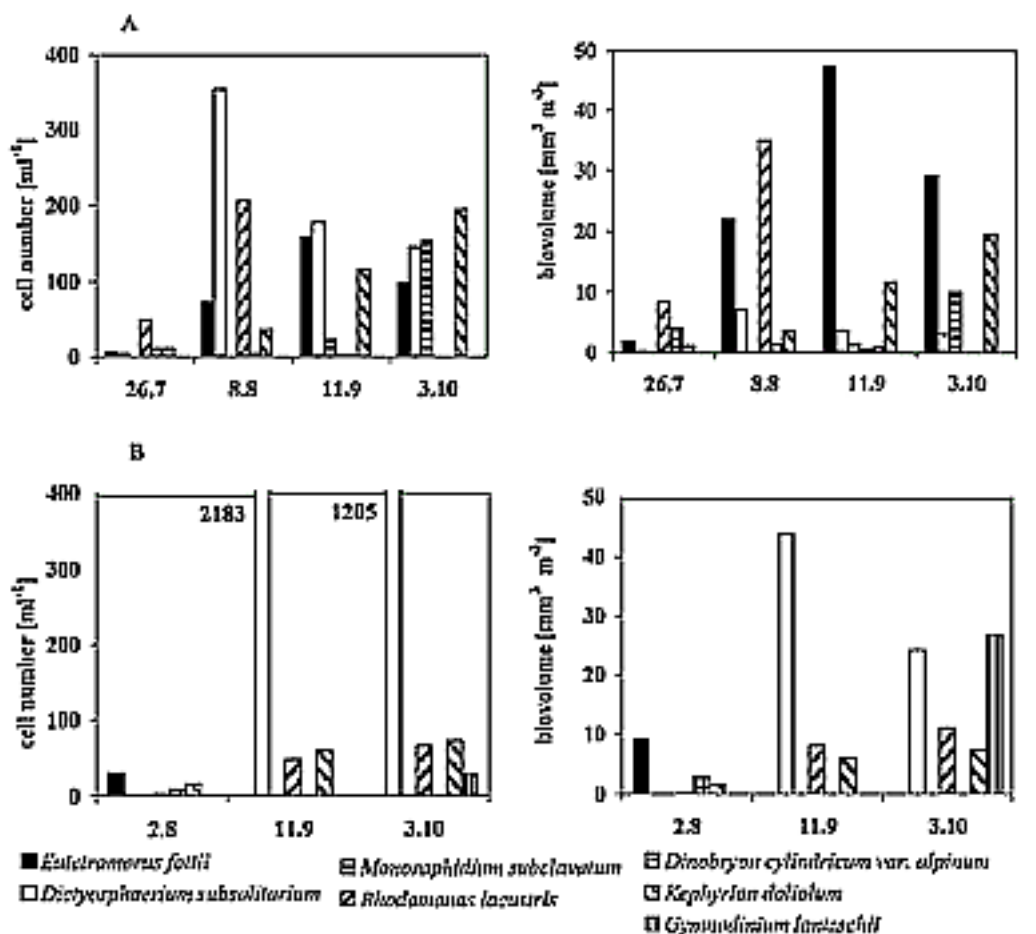

Fig. 2: Seasonal dynamics of dominant species of phytoplankton in 1996 in Jöri Lake III (A) and in Jöri Lake VII (B).

Tab. 4. Chlorophyll- $a\left(\mu \mathrm{g} \mathrm{l}^{-1}\right)$ in Jöri Lake III in 1996 (above) and 1997 (below).

\begin{tabular}{lccccccccccc}
\hline depth & 26.7 .96 & 8.8 .96 & 21.8 .96 & 22.8 .96 & 23.8 .96 & 10.9 .96 & 11.9 .96 & 12.9 .96 & 3.10 .96 & mean & s.d. \\
\hline $1 \mathrm{~m}$ & 0.4 & 0.4 & 0.5 & 0.6 & 0.6 & 1.1 & 1.2 & 1.5 & 2.3 & 1.0 & 0.7 \\
thermocline (4-6 m) & 0.8 & 1.6 & 1.7 & 2.0 & 1.9 & 1.4 & 1.6 & 1.7 & 2.1 & 1.6 & 0.4 \\
$10 \mathrm{~m}$ & 2.2 & 1.1 & 0.9 & 0.7 & 0.8 & 1.2 & 1.6 & 1.6 & - & 1.3 & 0.5 \\
$1 \mathrm{~m}$ above bottom & 1.1 & 0.4 & - & - & - & - & - & - & 2.4 & 1.3 & 1.4 \\
\hline & & & & & & & & & & & \\
\hline depth & 30.7 .97 & 14.8 .97 & 19.8 .97 & 26.8 .97 & 2.9 .97 & 9.9 .97 & 17.9 .97 & 23.9 .97 & 7.10 .97 & mean & s.d. \\
\hline $1 \mathrm{~m}$ & 1.0 & 1.1 & 0.7 & 0.6 & 0.8 & 0.7 & 0.7 & 0.9 & 1.1 & 0.8 & 0.2 \\
thermocline (4-5 m) & 0.8 & 1.0 & 0.7 & 0.9 & 0.6 & 1.8 & 1.2 & 1.6 & 1.2 & 1.1 & 0.4 \\
$10 \mathrm{~m}$ & 1.0 & 1.2 & 3.6 & 3.2 & 3.4 & 3.3 & 5.0 & 4.7 & 2.5 & 3.1 & 1.4 \\
$1 \mathrm{~m}$ above bottom & - & 1.0 & 0.9 & 1.2 & 0.9 & 1.3 & 1.2 & 0.9 & 0.9 & 1.0 & 0.2 \\
\hline
\end{tabular}

slightly lower than in 1997 (Tab. 4). The maximal concentration in $1996\left(2.4 \mu \mathrm{g} \mathrm{l}^{-1}\right)$ was only about half the maximal concentration of $1997\left(5.0 \mu \mathrm{g} \mathrm{l}^{-1}\right)$. Stratification persisted in both years for two months. In 1996 the highest chlorophyll- $a$ concentrations were found just below the thermocline (6 m depth) when the lake was stratified, although maximal chlorophyll concentrations were found in October when the lake was no longer stratified after a cold weather period in early September (Tab. 4). This supports the findings of Goldman et al. (1989) in subalpine lakes, that biomass production is highest after a relative long water column stratification followed by a sufficiently long mixing period. This allows to recirculate nutrients from the hypolimnion. In 1997, the highest values were found at the end of September a few meters below the thermocline in $10 \mathrm{~m}$ depth (Tab. 4). This correlates also with higher algal biomasses in this depth, although this correlation was not always reliable. Only very low amounts of photosynthetic active radiation (PAR) penetrates to this depth (maximal $5 \mu \mathrm{E} \mathrm{m}^{-2} \mathrm{~s}^{-1}$ ) and the temperature never exceeds $4{ }^{\circ} \mathrm{C}$ (Fig. 5). An advantage for algae to live at these depths are the slightly increased ion and nutrient concentrations (Fig. 5). In a different study, we have shown that the higher nutrient concentrations were always linked to increased turbidity due to suspended particles (data not shown). Algae could thus profit by living in a less oligotrophic environment. Moreover, algae living in the upper hypolimnion are less affected by sudden weather changes which happen usually at least once during the ice-free season. 

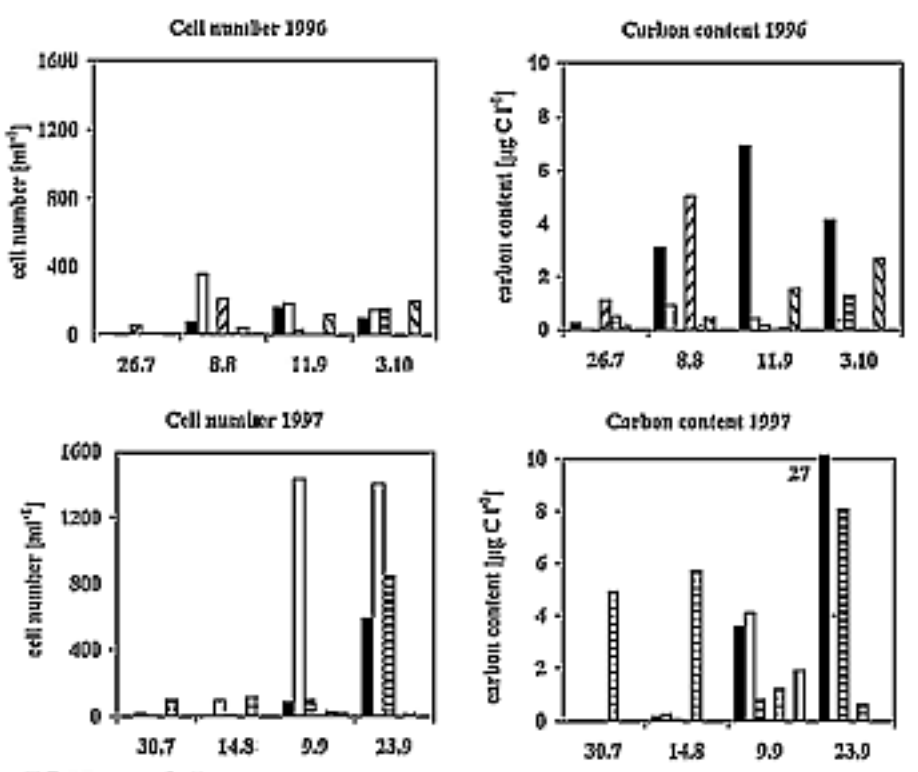

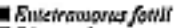

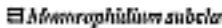

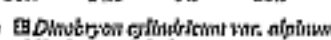

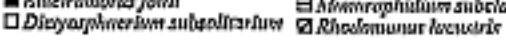

Fig. 3. Seasonal dynamics of dominant algal species on a cell number- and a carbon content-basis in Jöri Lake III in 1996 and 1997.

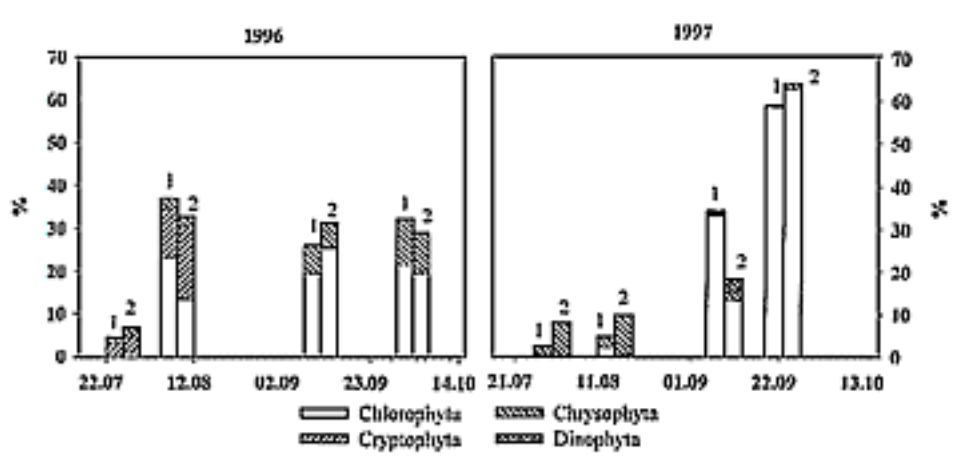

Fig. 4. Occurrence of algal divisions in Jöri Lake III in 1996 and 1997. 1: cell numbers (counts $\left.\mathrm{ml}^{-1}\right)$. 2: Carbon content $\left(\mathrm{pg} \mu \mathrm{m}^{-3}\right)$, both scaled to percentage. $100 \%$ is total annual cell counts, and carbon content, respectively.

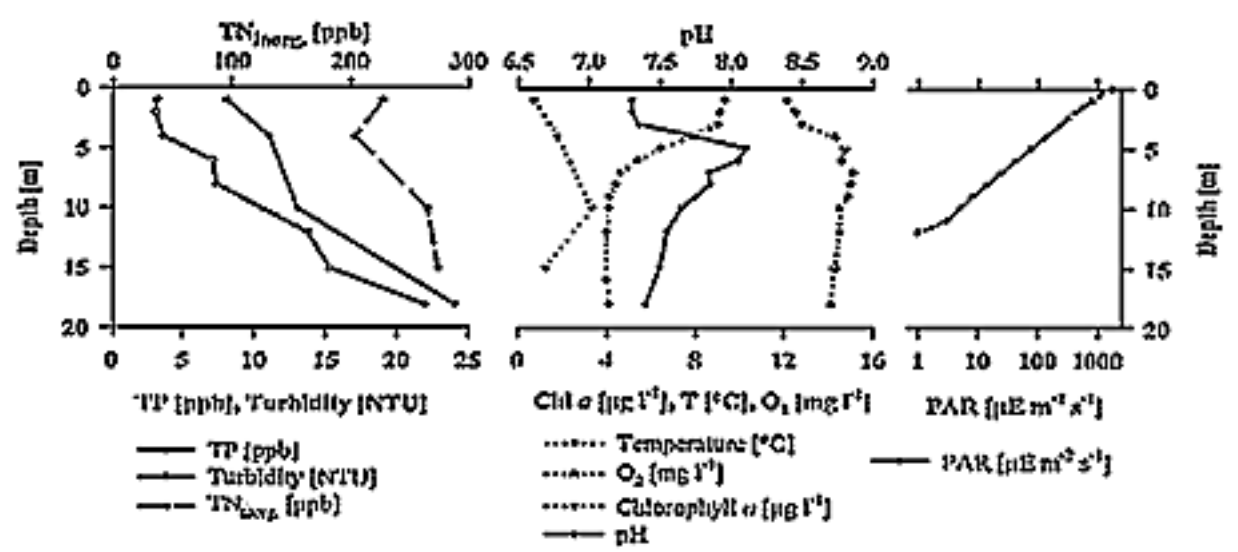

Fig. 5. Physical, chemical and biological parameters in the water column of Jöri Lake III on September 9, 1997. TP: total phosphorus, $\mathrm{TN}_{\text {inorg. }}$ : total inorganic nitrogen. 


\subsubsection{Effects of weather events on algae}

The effects of weather events on algae were recorded at the end of August 1997. During this period, lake profiles were taken once before and twice after a strong cold front. The lake was well stratified. The strong cold front hit the lakes at 15 UTC (Universal Time Coordinated) on August $28^{\text {th }}$, reducing air temperatures from $8{ }^{\circ} \mathrm{C}$ to $-2{ }^{\circ} \mathrm{C}$ within a few hours. Heavy snowfall built up a snow cover of about $30 \mathrm{~cm}$. Chlorophyll- $a$ concentration and $\mathrm{pH}$ were measured as indicators for the presence of algae and their photosynthetic activity, respectively. On August $26^{\text {th }}$, a maximum $\mathrm{pH}$ value of 7.84 was found at $4 \mathrm{~m}$ depth (Fig. 6). Surface water temperature decreased from $12{ }^{\circ} \mathrm{C}$ to $7{ }^{\circ} \mathrm{C}$ and stratification became less distinct. During this period of cold weather the thickness of the epilimnion increased. As the surface temperature decreased, the epilimnion was mixed and consequently approached the water temperature of the surface. Due to these lower temperatures, some of the original thermocline became isothermal, making the epilimnion thicker and the thermocline steeper. This process resulted in a one meter thicker epilimnion on September $9^{\text {th }}$, which is also reflected in the vertical pH-profile (Fig. 6).

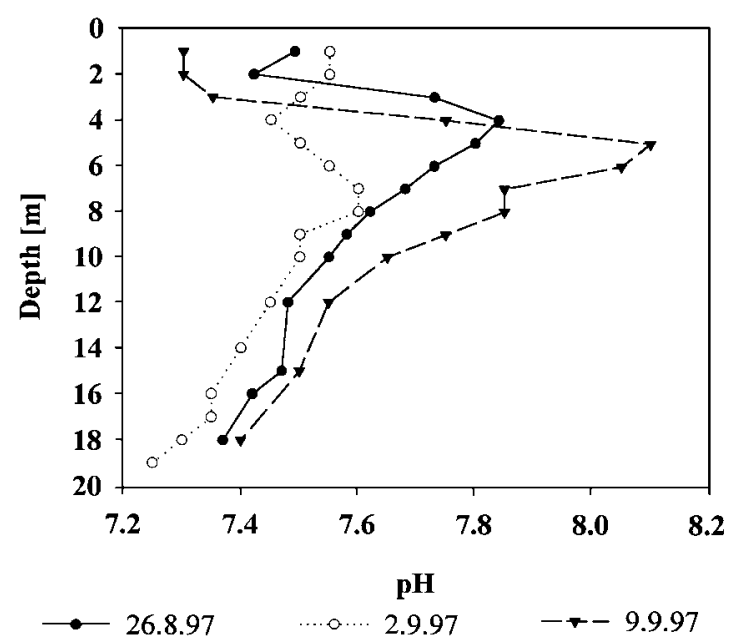

Fig. 6. Vertical profile of the $\mathrm{pH}$ in Jöri Lake III on three dates in 1997.

Low temperatures were recorded up to the morning of August $31^{\text {st }}$. Stratification intensified quickly again due to the large energy input during the first days of September. On September $2^{\text {nd }}$, two days after the cold front had passed by, a maximum $\mathrm{pH}$ value of 7.60 was found three to four meters deeper (Fig. 6). If photosynthesis was the main factor influencing the $\mathrm{pH}$, the proton consumption in seven to eight meters depth indicates restarting photosynthesis and suggests that primary production broke down during the storm. One week later, we again recorded a strongly increased proton production with maximal values at $5 \mathrm{~m}$ depth. A few days of sunshine doubled or even tripled the chlorophyll- $a$ concentration (Tab. 4). In $1 \mathrm{~m}$ depth, chlorophyll a concentrations were always low, probably due to rough living conditions. Chlorophyll- $a$ concentrations in $10 \mathrm{~m}$ depth were not affected by the cold front indicating stable environmental conditions in this layer.

\section{DISCUSSION}

During the two years of studying the environmental conditions in the Jöri lakes, high intra- and interannual variability was registered. The timing of the melting of the lake ice seems to strongly influence the starting conditions for the development of the phytoplankton. The community structure during the ice-free seasons differed distinctly. While Cryptophyta were frequent during the early season of 1996, they occurred only in low numbers in 1997 and were replaced by Chrysophyta. A large number of cysts, mostly of Chrysophyta, were observed in 1997 when the ice cover on the lake persisted until the end of August. Only little is known about the influence of the timing of lake ice melting on phytoplankton diversity. Scavia et al. (1986) hypothesized that abnormal phytoplankton biomass in 1977 in Lake Michigan could have been attributed to prolonged spring ice cover. Goldman et al. (1996) showed that horizontal differences in nutrients, phytoplankton and productivity in Lake Baikal - apart from other reasons probably reflected the variation in the timing of lake ice melting in different parts of the lake. The authors concluded that during the period of pre-stratification, phytoplankton growth in Lake Baikal is regulated by physical factors. However, we found only small diversity of phytoplankton after the late ice-break in 1997. Harris (1986) assumed that small diversity might be expected to occur in the seasonal sequence if species grow slowly in comparison to the rate of environmental change; for example when the lake undergoes major physical restructuring in spring and fall. In both years at Jöri, the dominant fraction of total biomass in the second part of the ice-free season was contributed by Chlorophyta. In 1997, when the weather was brighter and stable for almost two months, biomass production was higher than in 1996. This corroborates with the findings of Goldman et al. (1989) for subalpine lakes, that biomass production is highest if a relatively long water column stratification is followed by a sufficiently long mixing period.

Litaker et al. (1993) found that periodic ecological processes operating on time scales equivalent to phytoplankton cell division rates are important in controlling chlorophyll- $a$ biomass changes. Such an event was studied at the end of August 1997 when a cold front reached the lakes and surface water temperature was reduced from $12{ }^{\circ} \mathrm{C}$ to $7{ }^{\circ} \mathrm{C}$ in only a few hours. It took a few days to restore the chlorophyll- $a$ biomass in the epilimnion. Photosynthetic activity two days after the cold front had passed by, was still low. After one week sunny weather, it was completely restored or even 
higher than before the cold front had passed. The chlorophyll- $a$ biomass below the thermocline was not affected by this weather breakdown. In fact, chlorophyll- $a$ biomass was highest below the thermocline in 1997. We suggest, that algae live at these depths since the environmental conditions are more stable and the nutrients more abundant. In the frame of this study, migration of flagellated species has not been investigated. Higher nutrient concentrations might be linked to higher concentrations of suspended particles. Many studies demonstrated interactions between particulate matter and ions or nutrients (e.g., Cuker et al. 1990; Fukushima et al. 1991; Cuker 1993; Mez et al. 1998) and concluded that particulates can have strong effects on the nutrient situation in the lake and the phytoplankton community. Suspended particular matter entail also a different underwater light quality. Several authors have shown, that this is a controlling factor for phytoplankton growth as well (Glover et al. 1987; Talling 1971). Hence, the presence of suspended particles may also be a determinant for the phytoplankton community structure in the two Jöri lakes III and VII.

\section{CONCLUSIONS}

The seasonal succession and community structure of the phytoplankton was distinctly different in the two years during which they were studied. We suggest that the reasons for the variabilities are the different meteorological conditions. The timing of the lake ice melting might be most relevant to the development of some taxa: Rhodomonas lacustris was abundant in 1996, when the ice melted early (late June). In 1997, when the lake ice melted more than one month later, we found a great number of Chrysophyta cysts; the dominant fraction of total phytoplankton biomass was contributed by Dinobryon cylindricum var. alpinum. The phytoplankton community during mid- and end-season was dominated by Chlorophyta. Highest biomass production was observed at the end of the season 1997 after two months of stable stratification and following mixing of the water column. In 1997 the highest chlorophyll- $a$ concentrations were found several meters below the thermocline. This might be due to higher nutrient concentrations and more stable environmental conditions at this depth. The lakes containing and those lacking suspended particles showed similar phytoplankton diversity but different dominance of the algal species. According to the findings of Cuker et al. (1990), this could be due to the presence of the particles but also due to different light quality caused by the particles (Glover et al. 1987; Talling 1971).

\section{ACKNOWLEDGMENTS}

Research was supported by the EU Environment and Climate Programme (project MOLAR No. ENV4CT95-0007), financed by the Ministry of Education and Science of Switzerland (contract No. BBW 95.0518-2) and by a Swiss National Science Foundation Grant (CLEAR No. 5001-44614/1). We thank V. Summa and I. Baur for helping in the field, H.P. Schmidhauser and A. Birchmeier for the installation and maintenance of the field station, D. Högl (Institute for Atmospheric Science, Federal Institute of Technology, Zurich), and A. Vernez (Swiss Meteorological Service, Payerne) for the installation, and maintenance of the automatic data acquisition stations.

\section{REFERENCES}

Cuker, B.E. 1993. Suspended clays alter trophic interactions in the plankton. Ecology, 74(3): 944-953.

Cuker, B.E., P.T. Gama \& J.M. Burkholder. 1990. Type of suspended clay influences lake productivity and phytoplankton community response to phosphorus loading. Limnol. Oceanogr., 35(4): 830-839.

DEV (Deutsche Einheitsverfahren zur Wasser-, Abwasserund Schlammuntersuchung). 1996. Verlag Chemie, Weinheim.

Fukushima, T., M. Aizaki \& S. Ebise. 1991. Dynamics of particulate matter near the mouth of influx river in Takahamairi Bay of Lake Kasumigaura, with special reference to nitrogen and phosphorus. Jap. J. Limnol., 52(1): 13-26.

Glover, H.E., M.D. Keller \& R.W. Spinrad. 1987. The effects of light quality and intensity on photosynthesis and growth of marine eukaryotic and prokaryotic phytoplankton clones. J. Exp. Mar. Biol. Ecol., 105: 137-159.

Goldman, C.R., A. Jassby \& T. Powell. 1989. Interannual fluctuation in primary production: meteorological forcing at two subalpine lakes. Limnol. Oceanogr., 34: 310-323.

Goldman, C.R., J.J. Elser, R.C. Richards, J.E. Reuter, J.C. Priscu \& A.L. Levin. 1996. Thermal stratification, nutrient dynamics, and phytoplankton productivity during the onset of spring phytoplankton growth in Lake Baikal, Russia. Hydrobiologia, 331: 9-24.

Gran, G. 1950. Determination of the Equivalence Point in Potentiometric Titrations. Part I. Acta Chemica Scandinavica, 4: 559-573.

Gran, G. 1952. Determination of the Equivalence Point in Potentiometric Titrations. Part II. Int. Congress on Analytical Chemistry, 77: 661-671.

Gu, R., \& H.G. Stefan. 1990. Year-round temperature simulation of cold climate lakes. Cold Regions. Science and Technology, 18: 147-160.

Harris, G.P. 1986. Phytoplankton Ecology. Structure, function and fluctuation. Chapman and Hall, New York.

Johannessen, M., \& A. Henriksen. 1978. Chemistry of snow meltwater: Changes in concentration during melting. Water Resources Research, 14: 615-619.

Krähenbühl, R. 1984. Petrographisch-geologische Untersuchungen in der Silvretta-Masse vom Flüela Wisshorn zu Gorihorn und Rosställispitz (Kanton Graubünden). MSThesis, University of Bern.

Kreis, H.A. 1921. Die Jöriseen und ihre postglaziale Besiedlungsgeschichte. Eine faunistisch-biologische Studie. Int Rev. ges. Hydrobiol. Hydrogeog., 9: 189-212, 241-288, 451-490.

Lerman A., D.M. Imboden \& J.R. Gat. 1995. Physics and Chemistry of Lakes. $2^{\text {nd }}$ edition; Springer Verlag, Berlin Heidelberg.

Litaker, W., C.S. Duke, B.E. Kenney \& J. Ramus. 1993. Short-term environmental variability and phytoplankton abundance in a shallow tidal estuary. II. Spring and fall. Mar. Ecol. Prog. Ser., 94: 141-154.

Marchetto A., R. Mosello, M. Bianchi, H. Geiss, G. Serrini, G. Serrini Lanza, G.A. Tartari \& H. Muntau. 1996. Interlabo- 
ratory exercises to compare analytical methods performances. Mikrochimica Acta, 123(1-4): 95-102.

Messikommer, E. 1942. Beitrag zur Kenntnis der Algenflora und Algenvegetation des Hochgebirges um Davos. Verlag Hans Huber, Bern.

Mez, K., K. Hanselmann \& H.R. Preisig. 1998. Environmental conditions in high mountain lakes containing toxic benthic cyanobacteria. Hydrobiologia, 368: 1-15.

Minger U.A. 1996. Schwermetallkonzentrationen in Flechten und Moosen im Vergleich mit aktuellen Immissionen von Zink, Cadmium und Blei. Inauguraldissertation at the University of Bern; Bern.

Murphy, J. \& J.P. Riley. 1962. A modified single solution method for the determination of phosphate in natural waters. Anal. Chim. Acta, 27: 31-36.

Rocha, O. \& A. Duncan. 1985. The relationship between cell carbon and cell volume in freshwater algal species used in zooplanktonic studies. J. Plankton Res., 7(2): 279-294.
Scavia, D., G.L. Fahnenstiel, M.S. Evans, D. Jude \& J.T. Lehman. 1986. Influence of salmonine predation and weather on long-term water quality in Lake Michigan. Can. J. Fish. Aquat. Sci., 43: 435-443.

Schanz, F. 1982. A fluorimetric method of determining chlorophyll- $a$ and phaeophytin- $a$ concentrations. Arch. Hydrobiol. Beih. Ergeb. Limnol., 16: 91-100.

Straškrabová, V., C. Callieri, P. Carrillo, L. Cruz-Pizarro, J. Fott, P. Hartman, M. Macek, J.M. Medina-Sánchez, J. Nedoma \& K. Šimek. 1999. Investigations on pelagic food webs in mountain lakes - aims and methods. In: Straškrabová, V., C. Callieri \& J Fott (Eds), Pelagic food web in mountain lakes. MOuntain LAkes Research Program. J. Limnol., 58(2): 77-87.

Talling, J. F. 1971. The underwater light climate as a controlling factor in the production ecology of freshwater phytoplankton. Mitt. int. Ver. Limnol., 19: 214-243.

Wetzel, R.G. 1983. Limnology. $2^{\text {nd }}$ ed. Saunders College Publishing, Philadelphia: 767pp. 